Selcuk Journal of Agriculture and Food Sciences SJAFS

http://sjafs.selcuk.edu.tr/sjafs/index

(2019) 33 (2), 82-87

Research Article

\title{
Extending the Postharvest Quality of Peach Fruits by Salicylic Acid and MAP Treatments
}

\author{
Ferhan K. SABIR ${ }^{1, *}$, Sevil UNAL ${ }^{1}$, Mays Talal Kadhim MAADHEEDI ${ }^{2}$, Israa Mohammed Mahdi MAHDI ${ }^{2}$ \\ ${ }^{1}$ Selçuk University, Faculty of Agriculture, Department of Horticulture, Konya, Turkey \\ ${ }^{2}$ Selçuk University, Graduate School of Natural and Applied Science, Konya, Turkey
}

\begin{tabular}{l}
\hline ARTICLE INFO \\
\hline Article history: \\
Received date: 09.04 .2019 \\
Accepted date: 26.05.2019 \\
\hline Edited by: \\
Anamika PANDEY; Selçuk University, \\
Turkey \\
Reviewed by: \\
İhan CANAN; Bolu Abant İzzet Baysal \\
University, Turkey \\
Aşkin BAHAR; Selçuk University, \\
Turkey \\
\hline Keywords: \\
Peach \\
SA \\
MAP \\
Postharvest \\
Quality
\end{tabular}

\section{Introduction}

The peach (Prunus persica) is one of the most popular fruits in the world because of its high nutrient level and pleasant flavor. Peach is the third most important deciduous fruit crop in the world (Farooq et al. 2018). The world production of peach and nectarine is 24.7 million tons and the largest producer of peach fruit is China, followed by the United States, Italy, Turkey, Chile, Japan, Australia, and Russia. According to 2017 statistical data, total amount of peach-nectarine production of Turkey is 771.459 tons (FAO 2019).

Peaches are highly perishable climacteric fruits with limited market life. They would suffer rapid ripening and deterioration processes after harvest and thus, have a limited postharvest life at room temperature. Cold storage is widely used to extend the market life and postharvest quality by delaying the metabolic changes which deteriorate fruits quickly if the fruit is subjected to an ambient temperature after harvest (Farooq et al. 2018). However, fruits exposed to $0-1^{\circ} \mathrm{C}$ for up to 2-3 weeks cold storage may cause chilling

\footnotetext{
* Corresponding author email: fkbasmaci@selcuk.edu.tr
}

injury which is characterized by internal browning, mealiness, juicelessness, failure to ripen normally, leatheriness, and other imperfections related to the cell wall integrity and pectin metabolism (Awad 2013; Yenici and Akbudak 2014). Several other techniques used to improve the shelf life of peach are storage in controlled atmosphere, modified atmosphere packaging, heat treatment, chemical treatments and edible coatings (Farooq et al. 2018).

Salicylic acid (SA), a phenolic compound found in a wide range of plant species, exhibits a high potential in controlling the postharvest losses of horticultural crops. Postharvest SA treatments decrease the ethylene biosynthesis and action, induce the resistance towards disease, prevent oxidative stresses, support the fruit tolerance to chilling injury, decrease respiration rate, delay ripening and senescence, slow down the activity of cell wall degrading enzymes and maintain the crop firmness (Asghari and Aghdam 2010).

Modified atmosphere packages (MAP) have been commonly used in postharvest quality maintenance of horticultural crops. The use of MAP effectively extends the internal and external quality feature of the crops by restricting the respiration and ethylene biosyn- 
thesis. However, the effect of MAP on postharvest quality maintenance of the produces depends on genotypic structures of the species and cultivars as well as the maturity level, harvest quality and environmental conditions (Erkan ve ark. 2017).

In the present study, effects of SA and MAP on postharvest quality maintenance of fruits of peach cv 'J. H. Hale' were investigated.

\section{Materials and Methods}

The experiment was carried out during the growing seasons of 2016. Peach (Prunus persica) fruits of cv. 'J. H. Hale' were harvested at commercial mature stage (SSC at 9.20 and firmness at 25.50 N) in Karaman and transferred to postharvest laboratory of Department of Horticulture, Selcuk University within 3 hours of harvest. Fruits were sorted for uniform size and free from defects. Afterwards, fruits were randomly divided into four equal lots and each lot contained 120 fruits in three replicates. Two lots of fruits were immersed in $1.0 \mathrm{mM}$ salicylic acid aqueous solutions for $5 \mathrm{~min}$. Following the treatments, fruits were allowed to dry at room temperature. After SA treatment, the fruits of the first lot were packed with Xtend ${ }^{\circledR}$ MAPs (SA+MAP), while the others were directly placed into open plastic box (SA). Similar to untreated fruits, the first lot was stored in open plastic boxes without any application (as control) while the second was packed with MAPs (MAP).

After the treatments, all the fruits were stored at $0 \pm 1{ }^{\circ} \mathrm{C}$ and $90 \% \mathrm{RH}$ for 60 days. Fruits were analyzed for skin and flesh color, firmness, soluble solid content (SSC), titratable acidity (TA), total phenols (TP) and total antioxidant activity (TAA) after harvest and 15, 30,45 , and 60 days of cold storage.

Fruit firmness was measured using a digital penetrometer (fruit pressure tester, model 53205; TR, Forlì, Italy). After removing the epidermis at two equatorial sites, an $8 \mathrm{~mm}$ probe was used to measure the fruits firmness and results were expressed in Newton (N).

Fruit skin and flesh color were determined using a Minolta CR400 colorimeter to obtain the following variables from two equatorial points of fruits: $\mathrm{L}^{*}$ (lightness), $\mathrm{C}^{*}$ (chroma) and $\mathrm{h}^{\circ}$ (hue angle) (McGuire 1992).

Peach juice squeezed from fruit was analyzed for SSC using a refractometer (Atago, Tokyo, Japan) and results were expressed as SSC\%. TA was determined by the titration of $5 \mathrm{~mL}$ juice with $0.1 \mathrm{~N}$ sodium hydroxide to an end point of 8.1, results were given as the percentage of mallic acid (Cemeroğlu 2007). SSC/TA (Maturity index) was calculated as soluble solid content/acid content.

Fruit extracts for total phenol and antioxidant activity were prepared using method described by Thaipong et al. (2006) with some modifications. Five grams of peach tissue was homogenized in $25 \mathrm{~mL}$ methanol using the Ultra-Turrax homogenizer (IKA, T18 digital,
Staufen, Germany) for $5 \mathrm{~min}$. The homogenates were kept at $4{ }^{\circ} \mathrm{C}$ for $14-16 \mathrm{~h}$ and then centrifuged at $8000 \mathrm{x}$ $\mathrm{g}$ for $15 \mathrm{~min}$ at $5{ }^{\circ} \mathrm{C}$. The supernatants were recovered and stored at $-20{ }^{\circ} \mathrm{C}$ in dark color bottles until analysis.

Total phenolics were determined according to the method of Singleton et al. (1999) with slight modifications. The $0.1 \mathrm{~mL}$ extract, $6.0 \mathrm{ml}$ distilled water and 0.5 $\mathrm{ml}$ Folin-Ciocalteu reagent were mixed and vortexed. The mixture were incubated for $3 \mathrm{~min}$ and then $20 \%$ sodium carbonate solution was added and volume was made up to $10 \mathrm{ml}$ by adding distilled water. The solution was incubated at room temperature for $2 \mathrm{~h}$ and the absorbance was measured at $760 \mathrm{~nm}$. The total phenolics content was calculated on the basis of the calibration curve of gallic acid and was expressed as mg 100 $\mathrm{g}^{-1}$ FW.

Antioxidant activity was determined by the ferric reducing ability antioxidant power (FRAP) according to the procedure described by Benzie and Strain (1996). For this, $150 \mu \mathrm{L}$ of extract and $2.85 \mathrm{~mL}$ of the FRAP reagent was incubated at $30^{\circ} \mathrm{C}$ for $30 \mathrm{~min}$. After incubation, reaction mixture was measured at $593 \mathrm{~nm}$ on a UV-vis spectrophotometer. Standard curve was prepared using different concentrations of $1 \mathrm{mM}$ trolox and expressed as $\mu \mathrm{mol} \mathrm{kg}^{-1}$.

The experiment was a completely randomized design with three replications and each replication contained 10 fruits. Data from analyzed parameters was submitted to analysis of variance using JMP statistical software version 5.1 (SAS Institute Inc., Cary, NC, USA). Sources of variation were treatments, storage time and their interaction. Means were compared by Student's t-test at a significance level of 0.05

\section{Results and Discussion}

As illustrated in Fig. 1, firmness of the fruits gradually decreased during the prolonged cold storage. However, MAP and SA+MAP treatments significantly maintained the fruit firmness in comparison to control and SA fruits. Initial firmness value of peaches were $25.5 \mathrm{~N}$. At the end of the storage period, the highest firmness value was obtained from SA+MAP treatment $(19.8 \mathrm{~N})$, followed by MAP and SA treatment (17.4 and $11.8 \mathrm{~N}$, respectively). On the other hand, fruits of control treatment showed the lowest firmness value $(9.2 \mathrm{~N})$. Similar results were also obtained by Awad (2013) who reported that $0.5,1.0$ and $1.5 \mathrm{mM} \mathrm{SA}$ significantly inhibited the decrease of firmness in peach fruits.

Physiological effects of SA on the delaying the fruit softening was highlighted by Asghari and Aghdam (2010) who explained that SA inhibits the cell wall and membrane degrading enzymes such as polygalacturonase, lipoxygenase, cellulase and pectinemethylesterase. Results indicated that combined treatment was more effective than SA or MAP alone in delaying the softening during the storage period. This result was in agreement with Bal (2016) who reported a delaying 
effect of SA plus MAP on the firmness of nectarine cv. Fantasia.

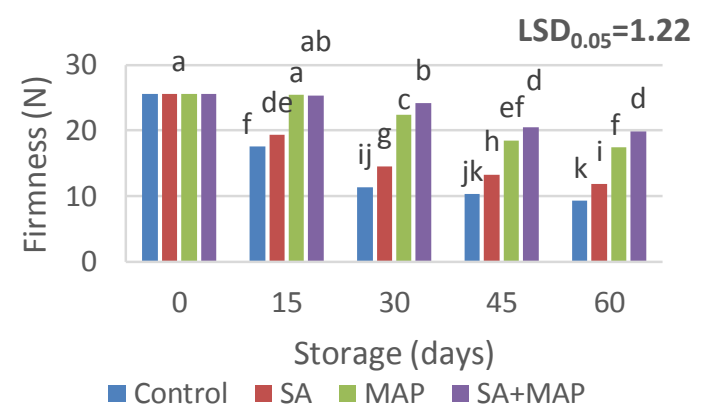

Figure 1

Changes in firmness values of peach fruits during the prolonged cold storage. Means not connected by same letter are significantly different at $5 \%$ level

Changes in total phenolics content of peach fruits in response to the different treatments during the prolonged cold storage was shown in Figure 2. Total phenolics content at harvest were 136.45 , while it ranged from 135.96 (MAP) to 140.63 (control) at $60^{\text {th }}$ day of storage. In general, a slight increase occurred in total phenolics content during the storage, but the effect of postharvest treatment on this decrease was insignificant. This result was in agreement with Lu et al. (2011) who reported that SA did not affect total phenolics content.

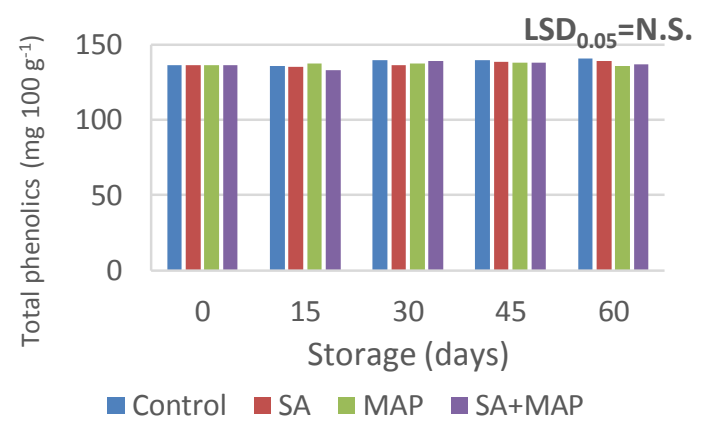

Figure 2

Changes in total phenolics of peach fruits during the prolonged cold strage. Means not connected by same letter are significantly different at 5\% level

After 15 days storage, antioxidant activity of peach fruits underwent a remarkable and significant decrease in all the treatments (Fig. 3). However, antioxidant activity degradation rate was significantly delayed by SA+MAP treatment. Among the treatments, SA+MAP maintained the highest antioxidant activity $(26.05 \mu \mathrm{mol}$ $\left.\mathrm{kg}^{-1}\right)$, while it was lowest in control fruits $(13.20 \mu \mathrm{mol}$ $\mathrm{kg}^{-1}$ ). In SA+MAP treated fruits, $50 \%$ more antioxidant activity was found as compared to the control fruits. As widely known, exogenously applied SA enhance the efficiency of antioxidant system in plants (Khademi and Ershadi 2013).

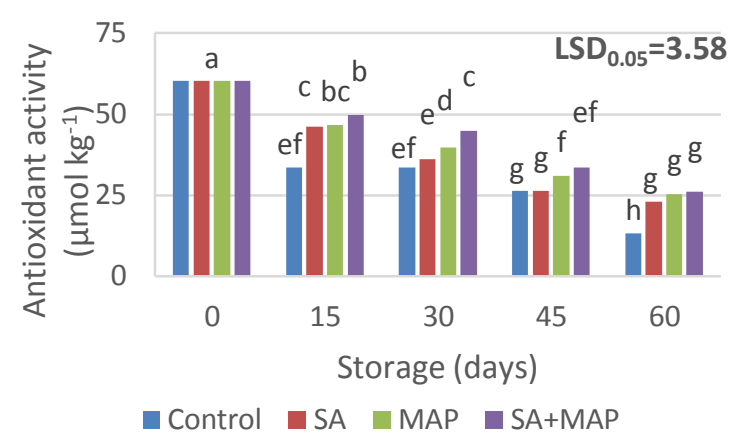

Figure 3

Changes in antioxidant activity of peach fruits during the prolonged cold storage. Means not connected by same letter are significantly different at 5\% level

Changes in the fruit skin color related values during storage were shown in Table 1. Significant decrease in the fruit skin $\mathrm{L}^{*}$ value was recorded with the prolonged storage time. At harvest, $\mathrm{L}^{*}$ value of fruit skin was 66.87. At the end of the storage, the highest $\mathrm{L}^{*}$ value was obtained from the fruits of the SA+MAP treatment (55.63), while the lowest value was measured in the control fruits (51.92). The chroma (C) value of the fruit skin also showed a significant decrease along with the prolonged storage time. At the beginning of the storage, $\mathrm{C}$ value of fruit was 46.02 while, this value ranged from 35.84 (control) to 38.71 (SA) at the end of the storage. Initial Hue angle values of the fruit skin was $74.04^{\circ}$. During the storage, the Hue angle significantly decreased probably due to the ripening process of fruits. At the end of the storage, SA+MAP combination was the most effective treatment with a significant delay as compared to control or single application of SA or MAP. Finally, Hue angle values of fruit skin ranged from $55.07^{\circ}$ (control) to $66.32^{\circ}$ (SA+MAP). 
Table 1

Changes in $\mathrm{L}^{*}, \mathrm{C}$ and Hue angle values of peach skin during the prolonged cold storage ${ }^{\mathrm{x}}$.

\begin{tabular}{|c|c|c|c|c|c|}
\hline \multirow[t]{2}{*}{ Treatments } & \multicolumn{5}{|c|}{ Storage (days) } \\
\hline & 0 & 15 & 30 & 45 & 60 \\
\hline & $\mathrm{L}^{*}$ & & & & \\
\hline Control & $66.87^{\mathrm{a}}$ & $60.95^{\mathrm{bc}}$ & $59.88^{\mathrm{cd}}$ & $58.72^{\mathrm{de}}$ & $51.92^{\mathrm{h}}$ \\
\hline SA & & $60.95^{\mathrm{bc}}$ & $58.67^{\mathrm{de}}$ & $56.88^{\mathrm{ef}}$ & $55.28^{\text {fg }}$ \\
\hline MAP & & $61.44^{\mathrm{bc}}$ & $58.33^{\mathrm{de}}$ & $55.25^{\mathrm{fg}}$ & $54.75^{\mathrm{g}}$ \\
\hline $\mathrm{SA}+\mathrm{MAP}$ & & $62.53^{\mathrm{b}}$ & $61.44^{\mathrm{bc}}$ & $58.02^{\text {de }}$ & $55.63^{\mathrm{fg}}$ \\
\hline & $\mathrm{C}$ & & & & \\
\hline Control & $46.02^{\mathrm{a}}$ & $44.40^{\mathrm{ab}}$ & $40.43^{\mathrm{c}-\mathrm{f}}$ & $37.92^{\text {fgh }}$ & $35.84^{\mathrm{hi}}$ \\
\hline SA & & $44.10^{\mathrm{ab}}$ & $41.63^{\mathrm{b}-\mathrm{e}}$ & $41.39^{\mathrm{b}-\mathrm{e}}$ & $38.71^{\mathrm{e}-\mathrm{h}}$ \\
\hline MAP & & $35.75^{\mathrm{hi}}$ & $41.82^{\mathrm{bcd}}$ & $33.53^{\mathrm{i}}$ & $36.15^{\text {ghi }}$ \\
\hline SA+MAP & & $43.74^{\mathrm{ab}}$ & $42.20^{\mathrm{bc}}$ & $39.03^{\mathrm{e}-\mathrm{h}}$ & $37.43^{\text {fgh }}$ \\
\hline & Hue angle & & & & \\
\hline Control & $74.04^{\mathrm{a}}$ & $70.60^{\mathrm{cd}}$ & $64.88^{\mathrm{g}}$ & $58.99^{\mathrm{i}}$ & $55.07^{\mathrm{j}}$ \\
\hline SA & & $71.19^{\mathrm{bcd}}$ & $67.60^{\text {ef }}$ & $62.37^{\mathrm{h}}$ & $57.69^{\mathrm{i}}$ \\
\hline MAP & & $71.61^{\mathrm{bc}}$ & $70.00^{\mathrm{d}}$ & $66.63^{\mathrm{ef}}$ & $64.89^{\mathrm{g}}$ \\
\hline $\mathrm{SA}+\mathrm{MAP}$ & & $72.40^{\mathrm{b}}$ & $68.12^{\mathrm{e}}$ & $66.41^{\mathrm{fg}}$ & $66.32^{\mathrm{fg}}$ \\
\hline
\end{tabular}

${ }^{\mathrm{x}}$ Means not connected by same letter are significantly different at $5 \%$ level. $\mathrm{LSD}_{0.05} \mathrm{~L}^{*}=1.93, \mathrm{C}=3.07$, Hue $=1.59$

Changes in $\mathrm{L}^{*}, \mathrm{C}$ and hue angle of fruit flesh color during the cold storage were illustrated in Table 2. Just similar to the findings on skin color, all the color values measures in the study markedly decreased during the cold storage and the decreases were statistically significant. Initial $\mathrm{L}^{*}$ value of peach flesh was 66.85 . The decrease in $\mathrm{L}^{*}$ values due to browning of flesh was highest in the control fruits (46.12) during the prolonged storage. At the 60th storage day, the highest $\mathrm{L}^{*}$ values was measured from the fruits of SA+MAP (51.81). Chroma value $(C)$ indicates the purity or intensity of color. C value of peaches at harvest was 43.14. After 60 days of storage, $\mathrm{C}$ value ranged from 36.89 (control) to 24.97 (MAP). At the end of the storage,
SA+MAP treatment was found as the most effective treatment for delaying the decrease in the Hue angle values, while the highest change was found in control fruits. The highest Hue angle value was found in fruits of SA+MAP (62.48) and was followed by SA (60.36), while the lowest value was obtained from control (54.29) and the fruits of MAP (54.22). Browning in fruit flesh is commonly seen in peach fruits during the cold storage due to cold injury (Lurie and Crisosto 2005). Previous studies on peach, plum and pomegranate indicated that SA have positive effects on preventing the flesh browning (Wang et al. 2006; Sabir 2017; Sayyari et al. 2009; Sharma and Sharma 2016).

Table 2

Changes in $\mathrm{L}^{*}, \mathrm{C}$ and Hue angle values of peach flesh during the prolonged cold storage ${ }^{\mathrm{x}}$.

\begin{tabular}{|c|c|c|c|c|c|}
\hline \multirow[t]{2}{*}{ Treatments } & \multicolumn{5}{|c|}{ Storage (days) } \\
\hline & 0 & 15 & 30 & 45 & 60 \\
\hline & $\mathrm{L}^{*}$ & & & & \\
\hline Control & $66.85^{\mathrm{a}}$ & $61.09^{b}$ & $52.91^{\mathrm{e}}$ & $49.68^{\mathrm{fg}}$ & $46.12^{\mathrm{h}}$ \\
\hline SA & & $60.12^{\mathrm{bc}}$ & $58.70^{\mathrm{cd}}$ & $53.53^{\mathrm{e}}$ & $47.66^{\mathrm{gh}}$ \\
\hline MAP & & $60.37^{\mathrm{bc}}$ & $58.88^{\mathrm{c}}$ & $53.68^{\mathrm{e}}$ & $48.55^{\mathrm{g}}$ \\
\hline SA+MAP & & $61.79^{\mathrm{b}}$ & $58.24^{\mathrm{cd}}$ & $56.67^{\mathrm{d}}$ & $51.81^{\mathrm{ef}}$ \\
\hline & $\mathrm{C}$ & & & & \\
\hline Control & $43.14^{\mathrm{a}}$ & $39.92^{\mathrm{b}}$ & $38.64^{\mathrm{bc}}$ & $30.49^{g}$ & $36.89^{\text {cde }}$ \\
\hline SA & & $39.45^{\mathrm{b}}$ & $35.95^{\mathrm{de}}$ & $36.93^{\text {cde }}$ & $28.90^{\text {gh }}$ \\
\hline MAP & & $33.45^{\mathrm{f}}$ & $39.70^{\mathrm{b}}$ & $36.61^{\text {cde }}$ & $24.97^{\mathrm{i}}$ \\
\hline $\mathrm{SA}+\mathrm{MAP}$ & & $34.80^{\text {ef }}$ & $38.64^{\mathrm{bc}}$ & $37.55^{\text {bcd }}$ & $27.41^{\mathrm{hi}}$ \\
\hline & Hue & & & & \\
\hline Control & $76.43^{\mathrm{a}}$ & $72.38^{c}$ & $61.64^{\mathrm{hi}}$ & $60.36^{\mathrm{ij}}$ & $54.29^{\mathrm{k}}$ \\
\hline SA & & $72.50^{c}$ & $71.51^{\mathrm{cd}}$ & $67.07^{\mathrm{f}}$ & $60.36^{\mathrm{ij}}$ \\
\hline MAP & & $72.76^{\mathrm{c}}$ & $69.88^{\mathrm{e}}$ & $63.26^{\mathrm{g}}$ & $54.22^{\mathrm{k}}$ \\
\hline $\mathrm{SA}+\mathrm{MAP}$ & & $74.64^{\mathrm{b}}$ & $70.17^{\text {de }}$ & $68.82^{\mathrm{e}}$ & $62.48^{\mathrm{gh}}$ \\
\hline
\end{tabular}

${ }^{\mathrm{x}}$ Means not connected by same letter are significantly different at $5 \%$ level. $\mathrm{LSD}_{0.05} \mathrm{~L}^{*}=2.15, \mathrm{C}=2.50$, Hue $=1.55$ 
SSC and SSC/TA displayed an overall increment while TA decreased across the treatments during cold storage (Table 3). Initial SSC value was $9.20 \%$ in peach fruits. At the end of the storage, the highest SSC was observed in SA (13.07\%), while the least value was recorded in SA+MAP combination (11.47\%). The increased amounts of SSC over the storage period could be due to weight loss and increased fruit juice concentration (Moreno et al, 2008). SA+MAP had positive effect on maintaining the SSC content of the peach fruit. Although certain researchers reported that single use of SA treatment had no effect on SSC of several fruits like grape Ranjbaran et al. (2011) and persimmon (Khademi et al. 2012).

At the beginning of the storage, TA was $0.635 \%$ and this value significantly decreased with the increase in storage period. After 60 days of storage, TA levels were $0.281 \%, 0.335 \%, 0.360 \%$ and $0.414 \%$ for control, SA, MAP and MAP plus SA, respectively. Previous studies indicated that SA treatment alone had no significant influence on TA of fruits over the storage time (Sayyari et al. 2009; Ranjbaran et al. 2011). In the present study, combined use of SA with MAP significantly prevented the decline in TA during the storage.

During storage, SSC/TA values tended to increase in various levels according to the treatments. At the end of the $60 \mathrm{~d}$ storage duration, the highest SSC/TA value was determined in control fruits (45.03). During the storage period, it was determined that postharvest treatments effectively delayed the increase in SSC/TA value compared to control.

Table 3

Changes in SSC, TA and SSC/TA values of peach during the prolonged cold storage ${ }^{\mathrm{x}}$.

\begin{tabular}{|c|c|c|c|c|c|}
\hline \multirow[t]{2}{*}{ Treatments } & \multicolumn{5}{|c|}{ Storage (days) } \\
\hline & 0 & 15 & 30 & 45 & 60 \\
\hline $\begin{array}{l}\text { Control } \\
\text { SA } \\
\text { MAP } \\
\text { SA+MAP }\end{array}$ & $\begin{array}{l}\text { SSC } \\
9.20^{\mathrm{j}}\end{array}$ & $\begin{array}{c}10.47^{\text {gh }} \\
10.67^{\mathrm{fg}} \\
9.93^{\mathrm{i}} \\
9.87^{\mathrm{i}}\end{array}$ & $\begin{array}{c}11.80^{\mathrm{c}} \\
11.27^{\mathrm{de}} \\
10.60^{\text {fgh }} \\
10.13^{\text {hi }}\end{array}$ & $\begin{array}{c}12.73^{\mathrm{ab}} \\
12.50^{\mathrm{b}} \\
11.47^{\mathrm{cd}} \\
10.93^{\mathrm{efg}}\end{array}$ & $\begin{array}{c}12.67^{\mathrm{ab}} \\
13.07^{\mathrm{a}} \\
11.47^{\mathrm{cd}} \\
11.00^{\mathrm{def}}\end{array}$ \\
\hline $\begin{array}{l}\text { Control } \\
\text { SA } \\
\text { MAP } \\
\text { SA+MAP }\end{array}$ & $\begin{array}{c}\text { TA } \\
0.635^{\mathrm{ab}}\end{array}$ & $\begin{array}{c}0.613^{\mathrm{b}} \\
0.670^{\mathrm{a}} \\
0.609^{\mathrm{bc}} \\
0.598^{\mathrm{bc}}\end{array}$ & $\begin{array}{c}0.440^{\mathrm{e}} \\
0.511^{\mathrm{d}} \\
0.526^{\mathrm{d}} \\
0.555^{\mathrm{cd}}\end{array}$ & $\begin{array}{c}0.298^{\text {hi }} \\
0.342^{\text {gh }} \\
0.361^{\text {fg }} \\
0.417^{\mathrm{e}}\end{array}$ & $\begin{array}{c}0.281^{\mathrm{i}} \\
0.335^{\text {ghi }} \\
0.360^{\mathrm{fg}} \\
0.414^{\text {ef }}\end{array}$ \\
\hline $\begin{array}{l}\text { Control } \\
\text { SA } \\
\text { MAP } \\
\text { SA+MAP }\end{array}$ & $\begin{array}{c}\text { SSC/TA } \\
14.56^{\mathrm{i}}\end{array}$ & $\begin{array}{l}17.15^{\mathrm{h}} \\
15.90^{\mathrm{hi}} \\
16.32^{\mathrm{hi}} \\
16.52^{\mathrm{hi}}\end{array}$ & $\begin{array}{c}26.80^{\mathrm{e}} \\
22.07^{\mathrm{f}} \\
20.14^{\mathrm{fg}} \\
18.26^{\mathrm{gh}}\end{array}$ & $\begin{array}{l}42.89^{\mathrm{a}} \\
36.58^{\mathrm{c}} \\
31.81^{\mathrm{d}} \\
26.23^{\mathrm{e}}\end{array}$ & $\begin{array}{l}45.03^{\mathrm{a}} \\
39.04^{\mathrm{b}} \\
31.87^{\mathrm{d}} \\
26.57^{\mathrm{e}}\end{array}$ \\
\hline
\end{tabular}

Means not connected by same letter are significantly different at $5 \%$ level. $\mathrm{LSD}_{0.05} \mathrm{SSC}=0.53, \mathrm{TA}=0.05, \mathrm{SSC} / \mathrm{TA}=2.38$

\section{Conclusions}

This study was performed to reveal the effects of SA and MAP on the postharvest quality maintenance of fruits of peach cv 'J. H. Hale'. Immersing the peach fruits in $1.0 \mathrm{mM} \mathrm{SA}$ aqueous solutions for $5 \mathrm{~min}$ had positive influences on postharvest quality maintenance of the fruits. However, combined use of SA and MAP was more effective in maintaining the firmness, delaying the biochemical changes with flesh and skin color than their single use. Therefore, storing the peach fruits in MAP after SA immersion could be recommended for postharvest cold storage.

\section{References}

Asghari M, Aghdam MS (2010). Impact of salicylic acid on post-harvest physiology of horticultural crops. Trends in Food Science \& Technology 21(10): 502-509.
Awad RM (2013). Effect of post-harvest salicylic acid treatments on fruit quality of peach cv." Flordaprince" during cold storage. Australian Journal of Basic and Applied Sciences 7(7): 920-927.

Bal E (2016). Combined treatment of modified atmosphere packaging and salicylic acid improves postharvest quality of nectarine (Prunus persica L.) fruit. Journal of Agricultural Science and Technology 18: 1345-1354

Benzie IFF, Strain JJ (1996). The ferric reducing ability of plasma (FRAP) as a measure of "antioxidantpower", The FRAP assay Analytical Biochemistry 239: 70-76.

Cemeroğlu B (2007). Gıda Analizleri, Gıda Teknoloji Derneği Yayınları, No:34 s:78-88.

Erkan M, Karaşahin YI, Pekmezci M (2017). Paketleme evi uygulamaları ve derim sonrası işlemler (Ed. Türk, R., Güneş, N.T. Erkan, M., Koyuncu, M.A.). Bahçe Ürünlerinin Muhafazası ve Pazara Hazırlanması. Somtad Yayınları Ders Kitabı s. 185-224 
FAO (2019). Production statistics http://www.fao.org/faostat/en/\#data/QC. (access date:28.04.2019)

Farooq S, Mir MM, Ganai SA, Maqbool T, Mir SA, Shah MA (2018). Postharvest biology and technology of peach. In Mir S, Shah M, Mir M (Eds) Postharvest Biology and Technology of Temperate Fruits Springer, Cham., pp. 169-199.

Khademi Z, Ershadi A (2013). Postharvest application of salicylic acid improves storability of peach (Prunus persica cv. Elberta) fruits. International Journal of Agriculture and Crop Sciences 5(6): 651.

Khademi O, Zamani Z, Mostofi Y, Kalantari S, Ahmadi A (2012). Extending storability of persimmon fruit cv. Karaj by postharvest application of salicylic acid. Journal of Agricultural Science and Technology 14 (5): 1067-1074.

Lu X, Sun D, Li Y, Shi W, Sun G (2011). Pre- and Post-harvest salicylic acid treatments alleviate internal browning and maintain quality of winter pineapple fruit. Scientia Horticulturae 130: 97-101.

Lurie S, Crisosto CH (2005). Chilling injury in peach and nectarine. Postharvest Biology and Technology 37: 195-208.

McGuire RG (1992). Reporting of objective color measurements. HortScience 27 (12): 1254-1255.

Moreno JJ, Cerpa-Caldero F, Cohen SD, Fang Y, Qian M, Kennedy JA (2008). Effect of postharvest dehydration on the composition of Pinot Noir grapes (Vitis vinifera L.) and wine. Food Chemistry 109(4): 755-762.

Ranjbaran E, Sarikhani H, Bakhshi D, Mehrdad P. (2011). Investigation of salicylic acid application to reduce postharvest losses in stored 'Bidaneh
Ghermez' table grapes. International Journal of Fruit Science 11: 430-439.

Sabır FK (2017). Erikte Salisilik Asit Uygulamalarının Soğukta Depolama Süresince Kalite Değişimlerine Etkisi. Meyve Bilimi 1 (Özel Sayı): 40-45.

Sayyari M, Babalar M, Kalantari S, Serrano M, Valero D (2009). Effect of salicylic acid treatment on reducing chilling injury in stored pomegranates. Postharvest Biology and Technology 53: 152-154.

Sharma S, Sharma RR (2016). Impact of staggered treatments of novel molecules and ethylene absorbents on postharvest fruit physiology and enzyme activity of 'Santa Rosa' plums. Scientia Horticulturae 198: 242-248

Singleton VL, Orthofer R, Lamuela-Ravento RM (1999). Analysis of total phenols and other oxidation substrates and antioxidants by means of folinciocalteu reagent. In L. Packer (Eds) Methods in enzymology. San Diego, CA: Academic Press, 299: 152-315.

Thaipong K, Boonprakob U, Crosby K, Cisneros ZL, Byrne DH (2006). Comparison of ABTS, DPPH, FRAP and ORAC assays for estimating antioxidant activity from guava fruit extracts. Journal of Food Composition and Analysis 19: 669-675.

Wang L, Chen S, Kong W, Li S, Archbold DD (2006). Salicylic acid pretreatment alleviates chilling injury and affects the antioxidant system and heat shock proteins of peaches during cold storage. Postharvest Biology and Technology 41: 244-251.

Yenici A, Akbudak, B (2014). 'Elegant Lady' şeftali çeşidinde hasat sonrası farklı uygulamaların muhafaza süresi ve meyve kalitesi üzerine etkisi. VI. Bahçe Ürünlerinde Muhafaza ve Pazarlama Sempozyumu 22-25 Eylül 2014, Bursa, 178-186. 